\title{
Influence of the Type of Strain Measurement Device and of the Speed of Loading and Unloading of the Testing Machine in the Determination of the Static Modulus of Elasticity of the Concrete
}

\author{
Suélio da Silva Araújo1, Gilson Natal Guimarães ${ }^{2}$ and André Luiz Bortolacci Geyer ${ }^{3}$ \\ ${ }^{1}$ Masters Degree in Civil Engineering from the Federal University of Goiás, Brazil (2011), School of Civil \\ Engineering, Research Assistanship from CNPq - National Council of Scientific and Technological \\ Development. \\ ${ }^{2} \mathrm{PhD}$., University of Texas at Austin, USA (1988). Full Professor at the Federal University of Goiás, Brazil. \\ ${ }^{3}$ Doctorate in Civil Engineering from the Federal University of Rio Grande do Sul, Brazil (2001). Associate \\ Professor II at the Federal University of Goiás.
}

\begin{abstract}
This paper presents a comparative analysis of the results obtained for testing the tensile modulus, through a collaborative program of tests on hardened concrete, developed at the School of Civil Engineering, Federal University of Goiás, in the Department of Technical Support and Control of Furnas central Electric Company SA and Carlos Campos and Construction Consultancy Limited., to identify and assess the influence of some factors involved in the test results the elastic modulus. This test was performed according to ABNT NBR 8522:2008, loading plan initial tangent modulus characterizing the deformation of concrete subjected to the stresses of $0.5 \mathrm{MPa}$ and $30 \%$ of the breaking load. For this, we sought to determine the outcome of the module, the influence of strain gauge (compressômetro mechanical, electrical bonding surface extensometer extensometer and electric external fixation) and rate $(0.3$ and $0.6 \mathrm{MPa} / \mathrm{s})$ bodies on the test piece cylindrical size $150 \mathrm{~mm} \times 300 \mathrm{~mm} \mathrm{C} 30$ concrete class. We performed 60 trials considering the results with satisfactory performance in the statistical techniques of the program. It was concluded that the strain gauge type of load and speed significantly influenced the results of elastic modulus. Moreover, it is noteworthy that the bodies of the test piece size $150 \mathrm{~mm} \times 300 \mathrm{~mm}$ concrete Class C30, tested with loading speed of the testing machine of 0.3 $\mathrm{MPa} / \mathrm{s}$ presented the results with the highest dispersion.
\end{abstract}

Keyword: Meter, Speed; Module; Concrete; Dispersion.

\section{INTRODUCTION}

Knowledge of the static modulus of elasticity of the concrete material is of fundamental importance both in the stages of design and implementation, as in any assessments about the quality of the structures in use. It is necessary to understand the concepts of the test requirements and the variables that influence, to interpret the results and to rule out possible discrepancies caused by deficiencies of the test equipment or operator.

Verification of the deformation becomes more important in the design of a structure, since for structural calculation approach a more faithful way of actual behavior of materials has to know, and the compressive strength of concrete, the module deformation, shrinkage, creep and all parameters that express the conditions of serviceability limit states.

In the particular case of the concrete, the modulus of elasticity determines its ability to deform and is a very important property for the calculation of reinforced concrete structures. The specification module mistaken for dimensioning the structural deformation may have serious consequences such as, for example, the occurrence of excessive deformations.

The research aims to study and evaluate the influence of variables: influence of strain gauge (compressômetro mechanical, electrical bonding surface extensometer extensometer and electric external fixation) and upload speed ( 0.3 and $0.6 \mathrm{MPa} / \mathrm{s})$ in cylindrical specimens of size $150 \mathrm{~mm} \times 300 \mathrm{~mm}$ in the concrete class $\mathrm{C} 30$, the result of static modulus of elasticity in hardened concrete and check the variability of the experimental result.

\section{EXPERIMENTAL PROGRAM}

Given the literature review presented identified some factors that may interfere with the test results of the experimental static modulus of elasticity. These factors are illustrated in Figure 2.1. 


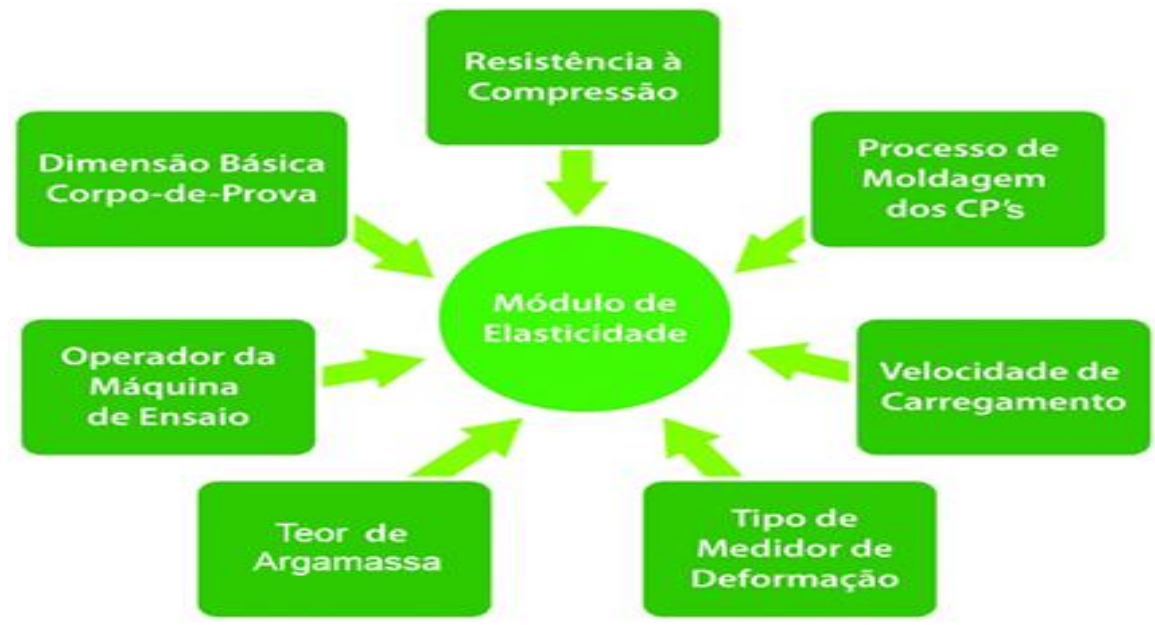

FIGURE 2.1 - Factors that interfere with the assay experimental result

The experimental program was developed from an evaluation of modulus of elasticity of concrete, developed in the Company Carlos Campos Consulting and Construction Ltd.., School of Civil Engineering, Federal University of Goiás and the Department of Technical Support and Control from Furnas SA.

Considering the characteristics of the program where it is not possible to fix all the independent variables, so we decided to study the following situation:

- $\quad$ concrete type (on one level: class C30);

- type of meter deflection (three levels: compressômetro mechanical, electrical bonding surface extensometer extensometer and electric external fixation);

- $\quad$ size of the samples in a level: $150 \mathrm{~mm}$ x $300 \mathrm{~mm}$;

- download speed (on two levels: $0.3 \mathrm{MPa} / \mathrm{s}$ and $0.6 \mathrm{MPa} / \mathrm{s}$ ) in cylindrical specimens of size $150 \mathrm{~mm} \times 300$ $\mathrm{mm}$ in the concrete class $\mathrm{C} 30$.

The Flowchart 2.1 presents the experimental study, showing the types of strain gages, size of the specimens, loading speeds and number of specimens tested (cp's).

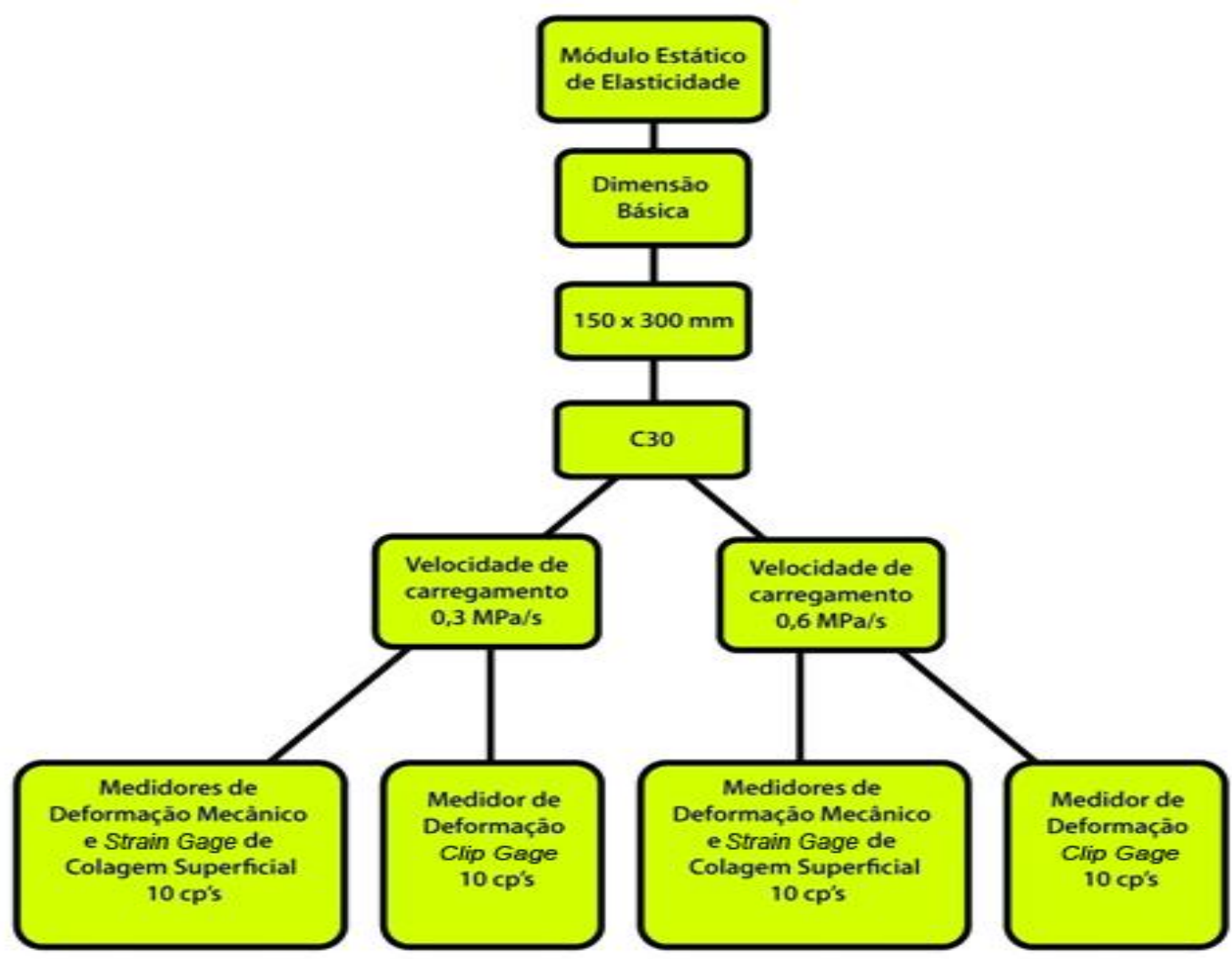

Flowchart 2.1 - Experimental Program - Modulus of Elasticity 
In Figure 2.2 ac shows the types of strain gages used in the study:

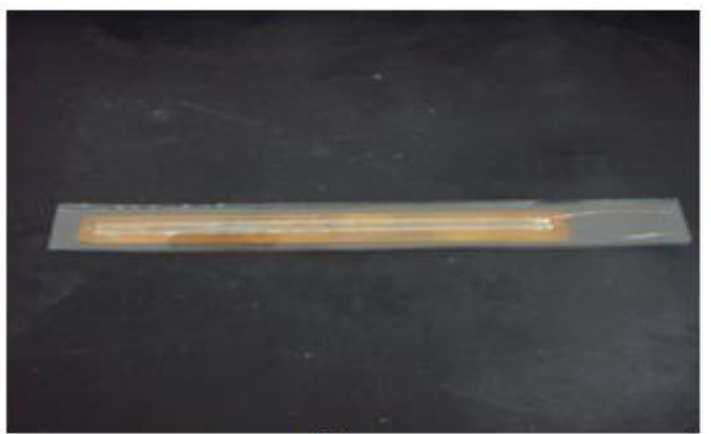

(a)

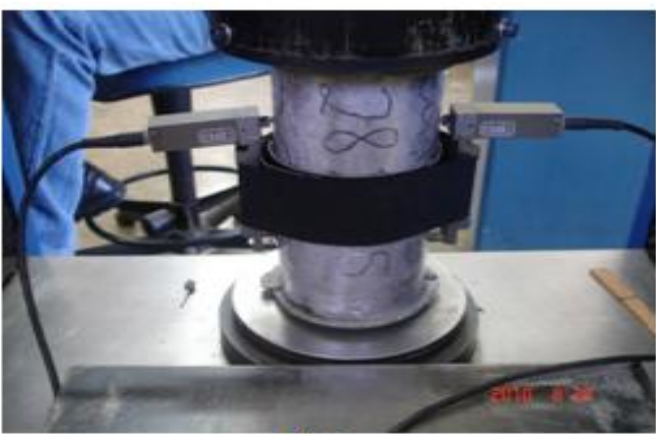

(b)

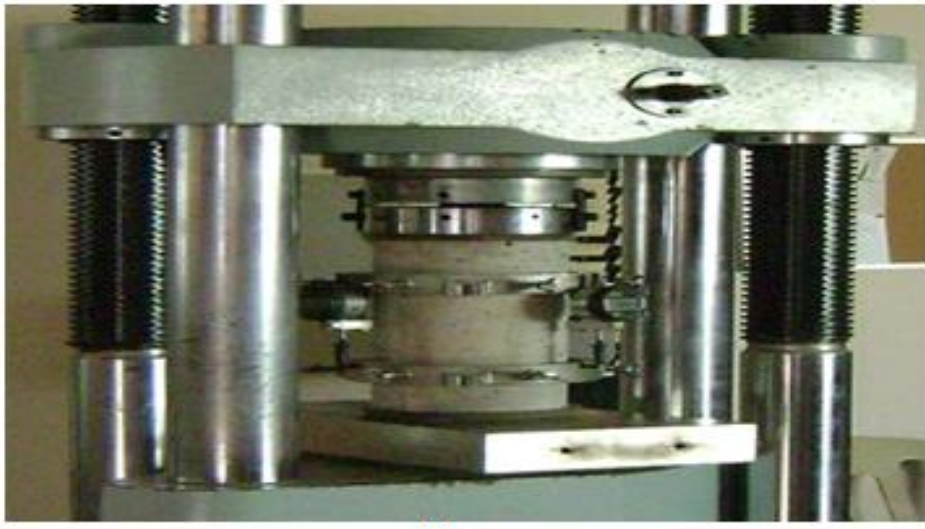

(c)

Figure 2.2 - Strain electrical bonding surface (a), electric extensometer external fixation (b) mechanical compressômetro (c)

As limitations of the study have been:

- Kept all the specimens in the same moisture condition;

- Modulus of elasticity (initial tangent plane load), as recommended in ABNT NBR 8522:2008, with application range $0.5 \mathrm{MPa}$ load at $30 \%$ of breaking load;

Testing machine with load control with load speed (in two levels: $0.3 \mathrm{MPa} / \mathrm{s}$ and $0.6 \mathrm{MPa} / \mathrm{s}$ ) in cylindrical specimens of size $150 \mathrm{~mm}$ x $300 \mathrm{~mm}$ in the concrete class C30 in phase study;

- Materials used in the manufacture of concrete: CP V ARI Portland cement (high early strength), lithology and size of coarse aggregate (granite maximum dimension of $19 \mathrm{~mm}$ ) and sand type (artificial sand);

- Compressive strength fc (28days) of $30 \mathrm{MPa}$;

- Type of finishing top of the specimens (capping with sulfur).

To reduce the influence of the humidity of the specimens, they were demolded 24 hours after mixing, identified and stored in storage tanks for 28 days, with controlled humidity and temperature as specified by the standard ABNT NBR 5738:2008. Once this term storage, the specimens were removed from the storage tank and stored in a dry environment at room temperature.

Regarding the charging speed, the standard ABNT NBR 8522:2008 determining the charging speed testing of elastic modulus in the range of $(0.45 \pm 0.15) \mathrm{MPa} / \mathrm{s}$.

The dosage concrete set concrete class for the sample C30 was obtained by adjustments of concrete mixtures resistance (fc) of about $30 \mathrm{MPa}$. It is noteworthy that the concrete was measured in a mixer with a capacity of 160 liters in two concreted, thus eliminating the effect of this factor on the results.

Were cast ten (10) specimens for the property modulus for each meter for each strain and loading speed of the testing machine, to meet the test methods ABNT NBR 5739:2007 e ABNT NBR 8522:2008.

\subsection{Technical Evaluation}

Was applied to the statistical analysis technique of variance (ANOVA) contained in Statistica Statsoft Software $7^{\circledast}$ to the results found in individual laboratories for the concrete samples Class C30 separately and together. The test methodology consists of the application of the Fisher Test (F). 


\section{PRESENTATIONS AND DISCUSSION OF RESULTS}

In order to evaluate the homogeneity of the concrete studied, the specimens were taken at break axial compression after running the test modulus. The results of the compressive strength were analyzed by statistical methods to verify the homogeneity in order to identify possible variations of results and checking the "normal" behavior results distribution (histogram).

FIGURES 3.1 and 3.2 respectively show histograms of the distribution of results of the compressive strength of laboratories A and B after being subjected to the test of static modulus of elasticity.

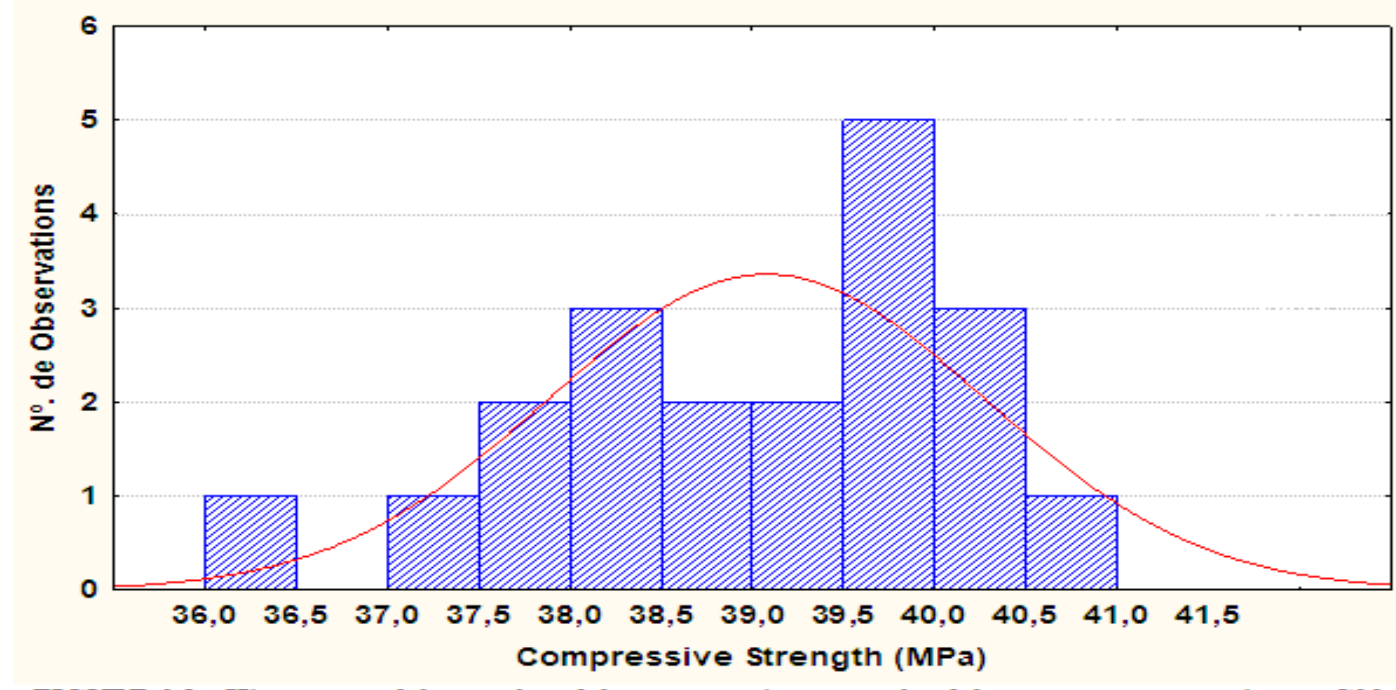

FIGURE 3.1 - Histogram of the results of the compressive strength of the concrete test specimens C30 Laboratory Class $A$, after being subjected to the test of static modulus of elasticity

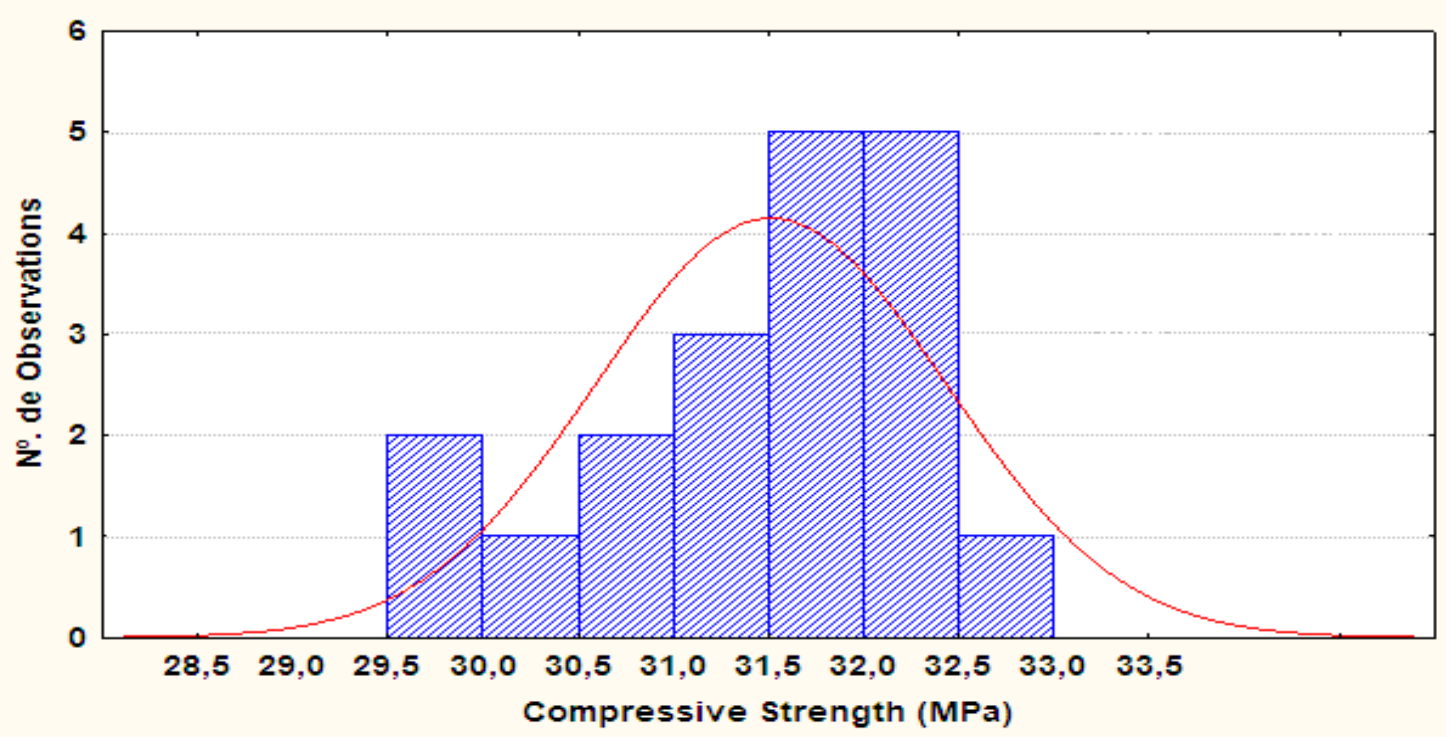

FIGURE 3.2 - Histogram of the results of the compressive strength of the concrete test specimens $\mathrm{C} 30$ Laboratory Class $B$ after being subjected to the test of static modulus of elasticity

The results of the compressive strength of the concrete class C30 Labs A and B shown in the histogram of Figure 3.1 and Figure 3.2 histogram showed an average of $39.1 \mathrm{MPa}$ respectively with a coefficient of variation of $3 \%$ and average $31.5 \mathrm{MPa}$ with a coefficient of variation of $3 \%$. The adhesion between the histograms and Normal distribution curve was demonstrated by the methods of Kolmogorov-Smirnov and Quisquare.

In Table 3.1 presents the means, standard deviations and coefficients of variation of the results for all study situations obtained for the sample C30 concrete class, with a confidence interval of the mean (for $95 \%$ confidence) and a significance level of 5\% property static modulus of elasticity. 
TABLE 3.1 - Statistical analysis of the test results - Static Module of Elasticity

\begin{tabular}{|c|c|c|c|c|c|c|c|}
\hline \multicolumn{4}{|c|}{ Situation of Study } & \multirow[b]{2}{*}{$\begin{array}{c}\mathbf{N}^{\circ} \text {. of } \\
\text { Specimen }\end{array}$} & \multicolumn{3}{|c|}{$\begin{array}{c}\text { Static Modulus of Elasticity } \\
(\mathrm{GPa})\end{array}$} \\
\hline $\begin{array}{c}\text { Size } \\
(\mathbf{m m})\end{array}$ & Type of strain measurement device & $\begin{array}{c}\text { Type of } \\
\text { Concrete }\end{array}$ & $\begin{array}{l}\text { Speed of the } \\
\text { Testing } \\
\text { Machine } \\
(\mathrm{MPa} / \mathrm{s})\end{array}$ & & $\begin{array}{c}\text { Average } \\
\text { (GPa) }\end{array}$ & $\begin{array}{c}\text { Standard } \\
\text { Deviation } \\
\text { (GPa) }\end{array}$ & $\begin{array}{c}\text { Coefficient } \\
\text { of Variation } \\
(\%)\end{array}$ \\
\hline- & - & - & - & 57 & 24,5 & 2,16 & 8,8 \\
\hline 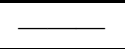 & Dial Indicators & - & 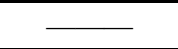 & 19 & 26,6 & 0,58 & 2,2 \\
\hline - & Electrical Surface Bonded Strain Gages & - & - & 18 & 25,0 & 1,59 & 6,3 \\
\hline & Externally Fixed Strain Gages & - & $\longrightarrow$ & 20 & 22,1 & 0,58 & 2,6 \\
\hline- & - & - & 0,3 & 29 & 25,0 & 2,19 & 8,8 \\
\hline- & - & - & 0,6 & 28 & 24,0 & 2,06 & 8,6 \\
\hline \multirow{6}{*}{$150 \times 300$} & Dial Indicators & \multirow{6}{*}{$\mathrm{C} 30$} & 0,3 & 10 & 26,8 & 0,43 & 1,6 \\
\hline & Dial Indicators & & 0,6 & 9 & 26,4 & 0,68 & 2,6 \\
\hline & Electrical Surface Bonded Strain Gages & & 0,3 & 9 & 25,9 & 1,50 & 5,8 \\
\hline & Electrical Surface Bonded Strain Gages & & 0,6 & 9 & 24,1 & 1,15 & 4,7 \\
\hline & Externally Fixed Strain Gages & & 0,3 & 10 & 22,3 & 0,66 & 2,9 \\
\hline & Externally Fixed Strain Gages & & 0,6 & 10 & 21,9 & 0,37 & 1,7 \\
\hline
\end{tabular}

Table 3.1 shows the types of strain gages having the smallest dispersions were compressômetro type mechanical and electrical extensometer external fixation because the total variation coefficients of these meters were respectively $2.2 \%$ and $2.6 \%$, and coefficient of variation of total electric meter gage bonding surface was $6.3 \%$.

TABLE 3.1 also shows that the specimens of size $150 \mathrm{~mm}$ x $300 \mathrm{~mm}$ tested with speed loading and unloading of the testing machine of $0.3 \mathrm{MPa} / \mathrm{s}$ have a greater dispersion of results, since the coefficient of variation of this full body proof tested with this speed was $8.8 \%$ and the coefficient of total variation of the specimen size $150 \mathrm{~mm}$ x $300 \mathrm{~mm}$ tested with speed loading and unloading of the testing machine of $0.6 \mathrm{MPa} / \mathrm{s}$ was $8.6 \%$, or the specimen dimension of $150 \mathrm{~mm}$ x $300 \mathrm{~mm}$ tested with the test machine speed of $0.3 \mathrm{MPa} / \mathrm{s}$ was $0.2 \%$ higher coefficient of variation compared with the test piece $150 \mathrm{~mm} \mathrm{x} 300 \mathrm{~mm}$ tested with the test machine speed of $0.6 \mathrm{MPa} / \mathrm{s}$.

We performed a statistical analysis of variance (ANOVA) of individual results of static modulus of elasticity to determine the statistically significant factors with a significance level of 5\% (ie, confidence level of $95 \%$ ). Some values were removed from the sample because they are outside the confidence interval and the same were considered spurious by Chauvenet criterion.

In Table 3.2 is the analysis of the significance of factors studied for the property static modulus of elasticity.

TABLE 3.2 - ANOVA - Analysis of the Global Experiment - Static Module of Elasticity

\begin{tabular}{|c|c|c|c|c|}
\hline Factors Studied & $\mathbf{S Q}$ & $\mathbf{F}$ & $\mathbf{p}$ & Result \\
\hline Model Study & 222,34 & 58,38 & 0,000 & significant \\
\hline Error (residual) & 38,85 & - & - & E- \\
\hline Total & 261,19 & & & \\
\hline \multicolumn{5}{|l|}{ Coefficient of Determination Model $\left(\mathrm{R}^{2}\right)=0,85$} \\
\hline Speed of the Testing Machine & $\longrightarrow$ & 14,56 & 0,000 & significant \\
\hline Type of Strain Measurement Device & - & 134,61 & 0,000 & significant \\
\hline Speed x Type of Strain Measurement Device & - & 3,73 & 0,031 & significant \\
\hline \multicolumn{5}{|c|}{$\begin{array}{l}\text { Where: } S Q=\text { sum of squares; } F=\text { parameter of Fischer to the test of significance of the effects; } p \\
=\text { probability of error involved in accepting the observed result as valid, this is, as representative of } \\
\text { the sample; Result }=\text { result of the analysis, indicating that the effect is significant or not, } \\
=(1-\mathrm{SQerro} / \mathrm{SQtotal}) .\end{array}$} \\
\hline
\end{tabular}


The analysis of variance showed compression strength of the resulting value of the coefficient of determination adopted $\left(\mathrm{R}^{2}\right)$ was 0.85 , which means that $85 \%$ of the total variance of the data of static modulus of elasticity can be explained by variables adopted. Therefore, uncontrolled factors accounted for approximately $15 \%$ of the variations observed in the study.

With respect to the influence of intensity, taking as a basis the magnitude of $F$ values, it can be seen the great influence of the strain gauge and the speed of loading and unloading of the testing machine results in elastic modulus.

The interaction effects were also statistically significant, that is, each strain gauge used depending on the speed of loading and unloading of the testing machine, the modulus of elasticity of the concrete presents difference result (different behavior).

In column $\mathrm{F}$ values of Table 3.2, the interactions involving the effect of speed of loading and unloading of the test machine showed the lowest values, indicating less influence of this variable on the results of static modulus of elasticity. Stands out even that speeds loading and unloading the machine test studied $(0.3 \mathrm{MPa} / \mathrm{s}$ and $0.6 \mathrm{MPa} / \mathrm{s}$ ), interacted with measuring deformation, significantly influenced the results.

As a result of ANOVA - Static Module of elasticity (Table 3.2) have revealed the significant effects of the variables velocity and strain gauge was held grouping of homogeneous medium by the method of Duncan, in order to observe the similarities and differences of the results obtained.

In this method, it was shown for both speeds studied the influence that the same values of the elastic modulus of concrete as the average overall static modulus of elasticity of the samples $150 \mathrm{~mm}$ x $300 \mathrm{~mm}$ tested speeds of loading and unloading the machine test of $0.3 \mathrm{MPa} / \mathrm{s}$ and $0.6 \mathrm{MPa} / \mathrm{s}$ respectively were $25.0 \mathrm{GPa}$ and $24.1 \mathrm{GPa}$, that is, the specimen $150 \mathrm{~mm} \times 300 \mathrm{~mm}$ tested with the test machine speed of $0,3 \mathrm{MPa} / \mathrm{s}$ was more than $4 \%$ average overall static modulus of elasticity over the specimen $150 \mathrm{~mm} \times 300 \mathrm{~mm}$ tested with the test machine speed of $0.6 \mathrm{MPa} / \mathrm{s}$.

After making grouping averages meter type strain by the method of Duncan, it was shown that the three strain gages have different results (different behaviors), because the overall averages of the strain gages compressômetro mechanical, electrical bonding surface extensometer extensometer and electric external fixation were respectively $26.6 \mathrm{GPa}, 25.0 \mathrm{GPa}$ and $22.1 \mathrm{GPa}$. Therefore, depending on the type of strain gauge used for testing the value of the modulus of elasticity is different.

FIGURE 3.3 shows a graphical analysis of the study, showing the results for each variable.

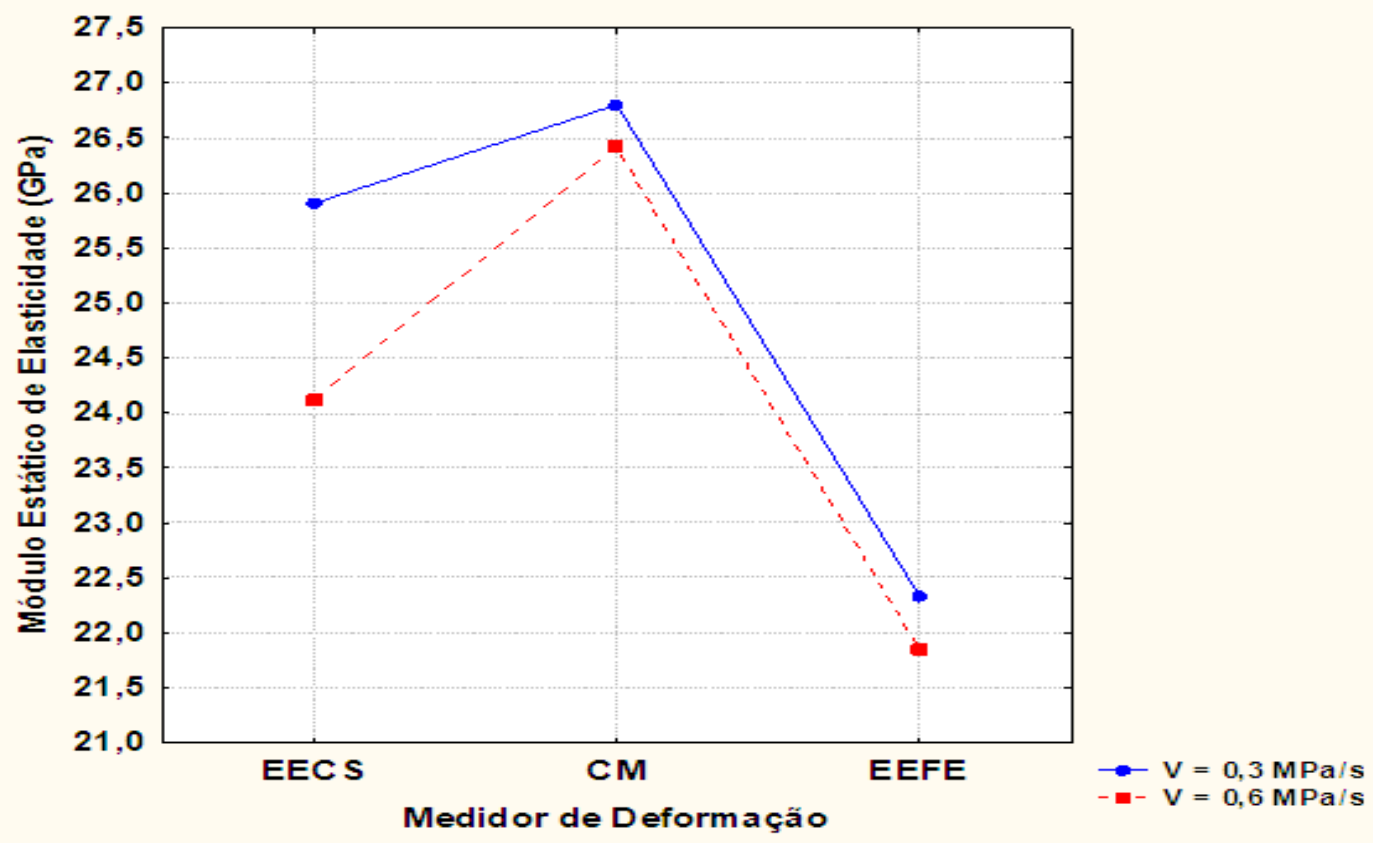

EIGURE 3.3 - Graphical presentation of study situations, divided by speed of loading and unloading of the testing machine and strain gauge, strain gauge and electrical bonding surface (EECS), compressômetro mechanical (CM) and electric extensometer external fixation (EEFE)

FIGURE 3.3 shows the values of elastic modulus are presented dispersed, exhibiting behavior ascending and descending between the measuring equipment electrical strain gages gage bonding surface compressômetro mechanical and electrical extensometer external fixation. 
As for the test specimens of size $150 \times 300 \mathrm{~mm}$ tested with charging and discharging speeds of the testing machine of $0.3 \mathrm{MPa} / \mathrm{s}$ and $0.6 \mathrm{MPa} / \mathrm{s}$, the results of tensile modulus in the strain gauge type electrical extensometer bonding surface, shown in Figure 3.3, showed averages of $25.9 \mathrm{GPa}$ and $24.1 \mathrm{GPa}$, and the coefficients of variation were $5.8 \%$ and $4.7 \%$. In measuring deformation compressômetro mechanical test specimens of size $150 \mathrm{~mm}$ x $300 \mathrm{~mm}$ tested with machine speed test of $0.3 \mathrm{MPa} / \mathrm{s}$ and $0.6 \mathrm{MPa} / \mathrm{s}$ had average elastic modulus of $26.8 \mathrm{GPa}$ and $26,4 \mathrm{GPa}$ and their coefficients of variation were $1.6 \%$ and $2.6 \%$. In the strain gauge extensometer electric external fixation, the results of modulus of elasticity of the specimens of size 150 $\mathrm{mm} \times 300 \mathrm{~mm}$ tested with machine speed test of $0.3 \mathrm{MPa} / \mathrm{s}$ and $0.6 \mathrm{MPa} / \mathrm{s}$ showed average $22.3 \mathrm{GPa}$ and 21.9 $\mathrm{GPa}$ and their coefficients of variation were $2.9 \%$ and $1.7 \%$.

As regards the size $150 \mathrm{~mm} \times 300 \mathrm{~mm}$ tested with loading and unloading speed of the testing machine of $0.3 \mathrm{MPa} / \mathrm{s}$, it was found that showed greater dispersion in electrical strain gages of gage surface sizing and external fixation electrical extensometer.

As regards the size $150 \mathrm{~mm}$ x $300 \mathrm{~mm}$ tested with loading and unloading speed of the testing machine of $0.6 \mathrm{MPa} / \mathrm{s}$, it was found that showed greater dispersion in the electrical extensometer strain gages bonding surface and mechanical compressômetro.

As for the meter mechanical deformation compressômetro used, it is emphasized that the equipment had the highest results of static modulus of elasticity. However, for changing the speed of loading and unloading of the testing machine, it was found that the strain gauge extensometer electric showed the highest surface sizing dispersions.

Because the specimens of size $150 \mathrm{~mm}$ x $300 \mathrm{~mm}$ tested with speed loading and unloading of the testing machine of $0.3 \mathrm{MPa} / \mathrm{s}$ had the highest dispersion of results, the variable speed was highlighted in the subsequent analysis, presented by Figure 3.4.

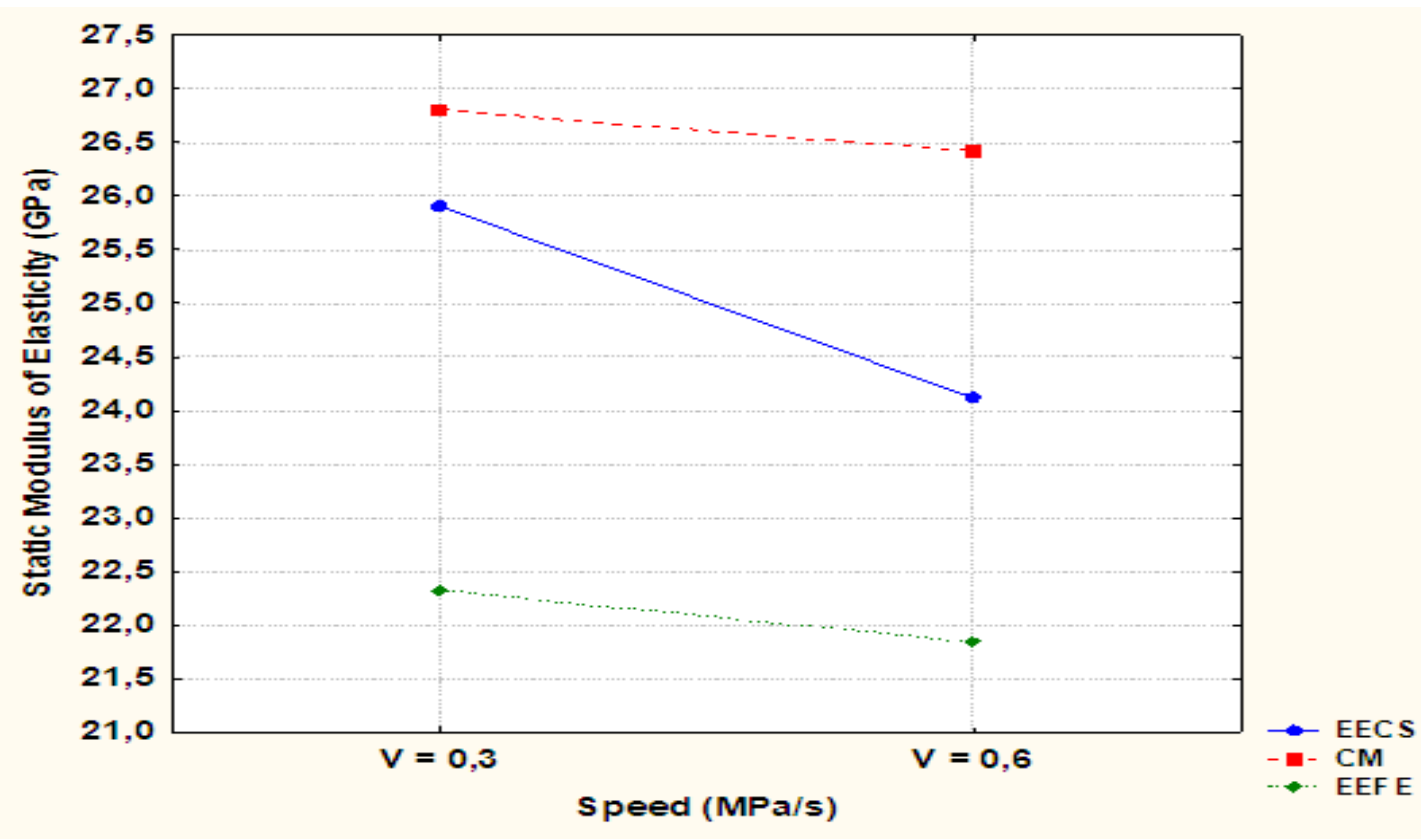

FIGURE 3.4 - Effect of loading and unloading speed of the testing machine and measuring strain comprising the values obtained by all the strain gauges, with electrical strain gauge bonding surface

Figure 3.4 shows the effect significant strain gauge, showing the behavior explained above and significant effect on the speed of loading and unloading of the testing machine, and the strain gauge compressômetro the average results presented mechanical static modulus of elasticity higher. Again should be subject to the high dispersions presented in strain gauge type extensometer electrical bonding surface as to speed loading and unloading of the testing machine.

\section{CONCLUSION}

The final considerations drawn from the presentation and analysis of results presented earlier considered: the influence of the strain gauge and the speed of loading and unloading of the testing machine, and the comparison between these variables obtained in the study and their applicability in the analysis and inspection of concrete structures.

1. In the method of Duncan, it was shown that both the charging and discharging speeds studied the influence 
values of the elastic modulus of concrete as the average overall static modulus of elasticity of the samples tested speeds of loading and unloading of the testing machine $0.3 \mathrm{MPa} / \mathrm{s}$ and $0.6 \mathrm{MPa} / \mathrm{s}$ respectively were $25.0 \mathrm{GPa}$ and $24.1 \mathrm{GPa}$.

2. When used two speed loading and unloading, after making grouping averages meter type strain by the method of Duncan, it was shown that the three strain gages have different results (different behaviors), as the general averages of meters deformation compressômetro mechanical, electrical bonding surface extensometer extensometer and electric external fixation were respectively $26.6 \mathrm{GPa}, 25.0 \mathrm{GPa}$ and 22.1 $\mathrm{GPa}$. Therefore, depending on the type of strain gauge used for testing the value of the modulus of elasticity shows small variations determined within the limits of tolerance set forth by the item 8.2 of the ABNT NBR 8522:2008, admitting variations in results that are not higher than $10 \%$.

3. When used two speed loading and unloading, the greatest results of static modulus of elasticity happened when we used the compressômetro mechanic. However, the strain gauge extensometer electrical bonding surface had the highest dispersions.

4. The behavior of the results of the tests performed with concomitant use of compressometro mechanical and electrical strain gage bonding surface indicated regularity and proximity of the strain readings.

5. The electrical extensometer external fixation has the advantage of providing measurements of longitudinal and transverse deformation, it has to read digital display of the deformations and presents less susceptible to variations in calibration. The electrical extensometer external fixation can be reused several times and their assembly with the specimen takes place smoothly and without great skill by the operator of the test.

6. The two electric resistive strain gauges showed significant advantages such as less need for external influence during the test and minimizing the possibility of read errors by the operator. In the case of electrical extensometer bonding surface for bonding the same to the concrete surface, several aspects need to be guarded to preserve the strain readings, making it difficult to use. Furthermore, this type of transducer should be discarded after the test, not intended for a second collage.

As all tests were performed according to the requirements of judiciously of the ABNT NBR 8522:2008, were clear limitations of the test, the influence of strain gages and care necessary both in the execution and interpretation of tests for determining the static modulus of elasticity of the concrete.

The modulus of elasticity tests using different types of strain gages demonstrated that even following the criteria proposed in ABNT NBR 8522:2008, variations in test results are relatively large.

It is noted that the results obtained here are valid for materials and test conditions adopted, so you should consider this limit the search.

\section{ACKNOWLEDGEMENTS}

To all of the Master Course in Civil Engineering, School of Civil Engineering, Federal University of Goiás. To all Company Carlos Campos Consulting and Construction Ltda., the unconditional support and assistance in the execution of the experimental program. To all the staff of Furnas, the suggestions, availability, willingness and readiness to always demonstrated. To all of Realmix and all the Quarry Anhanguera, for providing access aggregates and cement, that every question or request, were always ready to help. The tutor Gilson Natal Guimarães and co-supervisor Professor André Luiz Bortolacci Geyer, the teachings transmitted.

And the teachers of the Master Course in Civil Engineering, School of Civil Engineering, Federal University of Goiás (CMEC - EEC - UFG), the valuable information provided.

This study was conducted with the support of the Federal University of Goiás and the National Council for Scientific and Technological Development - CNPq - Brazil.

In Brazilian society, which, by the Federal University of Goiás, CNPq and Procad/Capes have provided my scholarship and funded the materials needed for research.

\section{REFERENCES}

[1]. ARAÚJO, SUÉLIO DA SILVA. Influência do tipo de medição na determinação do módulo estático de elasticidade do concreto [manuscrito] / Suélio da Silva Araújo. - 2011. xxxv, 212 f.: il., figs, tabs. Orientador: Prof. PhD. Gilson Natal Guimarães; Co-orientador: Prof. Dr. André Luiz Bortolacci Geyer. Dissertação (Mestrado) - Universidade Federal de Goiás, Escola de Engenharia Civil, 2011.

[2]. ASSOCIAÇÃO BRASILEIRA DE NORMAS TÉCNICAS - ABNT. NBR 5738: Concreto Procedimento para moldagem e cura de corpos de prova. Rio de Janeiro: ABNT, 2008.

[3]. NBR 5739: Concreto - Ensaio de compressão de corpos de prova cilíndricos. Rio de Janeiro: ABNT, 2007.

[4]. NBR 8522: Concreto - Determinação do módulo estático de elasticidade à compressão e Diagrama Tensão-Deformação - Método de Ensaio. Rio de Janeiro: ABNT, 2008.

[5]. BEER, F. P.; JOHNSTON Jr, E. R. J. Resistência dos Materiais. 3. ed. São Paulo: MAKRON Books do Brasil Editora Ltda., 1995. 1255 p. 
[6]. CUPERTINO, M. A.; PEREIRA, A. C; INÁCIO, J.J.; ANDRADE, M.A.S. Avaliação de Fatores de Ensaio que Interferem nos Resultados de Módulo de Elasticidade do Concreto. In: $49^{\circ}$ CONGRESSO BRASILEIRO DO CONCRETO, 2007, Bento Gonçalves - RS. Anais $49^{\circ}$ Congresso Brasileiro do Concreto. 2007. CD-ROM.

[7]. Equipe de FURNAS. Módulo de Elasticidade e Coeficiente de Poisson. In: Concretos massa, estrutural, projetado e compactado com rolo - Ensaios e Propriedades. Editor: ANDRADE, W. P. Pini, São Paulo. 1997. cap. 6, p. 6.1-6.64.

[8]. FIGUEIREDO, E. J. P.; SOUZA, F. L. S.; DE FIGUEIREDO, A. D. Medidas de deformação através de strain gages. Trabalho da disciplina de tecnologia avançada no estudo do comportamento do concreto. São Paulo, 1989. 57 p.

[9]. JACINTHO, A.E.P.G. de Ávila; GIONGO, J.S. Resistência Mecânica do Concreto. In: IBRACON, Concreto: Ensino, Pesquisa e Realizações. Editor: ISAIA, G. S. IBRACON, São Paulo, 2005. cap. 20, p. 605-632. ISBN 85-98576-03-4.

[10]. METHA, P. K.; MONTEIRO, Paulo J. M. "Concreto-Microestrutura, Propriedades e Materiais.” $1^{\text {a }}$ Ed. Português, IBRACON, São Paulo, 2008.

[11]. MARTINS, DANILO GOMES. Influência do tamanho do corpo de prova nos resultados de ensaios de módulo de deformação e resistência à compressão e suas correlações para concretos produzidos em Goiânia-GO [manuscrito] / Danilo Gomes Martins. - 2008. Dissertação (Mestrado) - Universidade Federal de Goiás, Escola de Engenharia Civil, 2008.

[12]. MONTIJA, Fernando Celloto. Aspectos da Variabilidade Experimental do Ensaio de Módulo de Deformação do Concreto. 2007. Dissertação (Mestrado em Engenharia de Construção Civil e Urbana) Escola Politécnica, Universidade de São Paulo, São Paulo, 2007.

[13]. NEVILLE, A. M. Propriedades do concreto. Adam M. Neville; tradução Salvador E. Giammusso. - 2. ed. rev. atual. - São Paulo: Pini, 1997-b. 182.

[14]. RODRIGUES, G. S. S. Módulo de deformação estático do concreto pelo método ultra-sônico: estudo da correlação e fatores influentes. Dissertação de Mestrado. Escola de Engenharia Civil, Universidade Federal de Goiás. 2003. 234 p.

[15]. SHEHATA, L. D. Deformações Instantâneas do Concreto. In: IBRACON, Concreto: Ensino, Pesquisa e Realizações. Editor: ISAIA, G. S. IBRACON, São Paulo, 2005. cap. 21, p. 633-654. ISBN 85-98576-034.

[16]. VASCONCELOS, A. C.; GIAMMUSSO, S. E. O misterioso módulo de elasticidade. In: CONGRESSO BRASILEIRO DO CONCRETO, 40., 1998, Rio de Janeiro. Anais. São Paulo: Instituto Brasileiro do Concreto, 1998. CD-ROM - Tabalho_090. 